\title{
First report of citrus leaf blotch virus in Satsuma mandarin in Korea
}

\author{
Chung Youl Park ${ }^{1,2} \cdot$ Jeongran Park ${ }^{1} \cdot$ Hongsup Kim ${ }^{1} \cdot$ Seung-In $\mathrm{Yi}^{1} \cdot$ Jae Sun Moon ${ }^{3}$
}

Received: 12 November 2018 / Accepted: 14 March 2019 / Published online: 1 April 2019

(C) The Author(s) 2019

Keywords Citurs leaf blotch virus $\cdot$ RNA sequencing $\cdot$ Satsuma mandarin

Satsuma mandarin (Citrus unshiu) is an economically important fruit in Korea, and more than $90 \%$ of the fruit is produced in Jeju Island. To determine the presence of viruses in satsuma mandarin, a survey was performed in Jeju Island in 2017. Leaf samples were collected from three trees with virus-like symptoms such as leaf blotch, chlorosis, distortion, and enation. All samples were mixed and ground in liquid nitrogen. Total RNA was subsequently extracted from this mixed sample by the NucliSENS EasyMAG biorobot (Biomérieux, Marcy l'Etoile, France) for RNA sequencing. A total of 295,758,098 reads obtained via Illumina HiSeq 100 bp paired-end RNA sequencing were analyzed as described by Lim et al. (2017). The resulting four viruses (citrus leaf blotch virus, CLBV; citrus tristeza virus, $\mathrm{CTV}$; citrus vein enation virus, $\mathrm{CVEV}$; and satsuma dwarf virus, SDV) were identified. Twenty-one contigs with high sequence similarities to citrus leaf blotch virus (CLBV), with an average length of $1319 \mathrm{bp}$, were identified. The largest contig (2112 bp) had 92\% sequence identity with the CLBV NZ_G78 isolate (EU857540). A primer pair, CLB-F (5'-GCAA GACACTCTGTCTCAAAT-3') and CLB-CP-R (5'-ATAG GTATCTACTCCAAAAAGG-3'), was designed according to the contig sequence and used to test all samples in reverse transcription (RT)-PCR. An amplicon of the expected size (214 bp) was obtained from three trees, and CLBV-infection was confirmed by direct sequencing. Of the three CLBV-positive leaf

Jae Sun Moon

jsmoon@kribb.re.kr

1 Seed Testing \& Research Center, Korea Seed \& Variety Service, Gimcheon 39660, South Korea

2 Seed Vault Department, Baekdudaegan National Arboretum, Bonghwa 35208, South Korea

3 Plant Systems Engineering Research Center, Korea Research Institute of Bioscience and Biotechnology, Daejeon 34141, South Korea samples, two exhibited blotch symptoms, and one exhibited chlorosis. To determine the complete sequences of CLBV coat protein gene isolated from satsuma mandarin, RT-PCR using a primer set (5'-ACTGCCAGTGACACTGGGA-3' and 5'GTGTAAAGTCCTGGCCCAC-3') was performed on one CLBV-positive sample, and an amplicon (1228 bp) was purified, cloned, and sequenced. Sequence analysis showed that this isolate (GenBank Accession No. LC416591) shared 97-99\% nucleotide sequence identity with previously reported CLBV isolates from citrus plants. To the best of our knowledge, this is the first report of CLBV in Korea. CLBV could infect sweet cherry and kiwifruit (Chavan et al. 2013; Wang et al. 2016). Therefore, further investigation is needed to assess the extent and impact of CLBV infections in Korea.

Funding This work was supported by Korea Institute of Planning and Evaluation for Technology in Food, Agriculture and Forestry (IPET) through Agri-Bio industry Technology Development Program, funded by Ministry of Agriculture, Food and Rural Affairs (MAFRA)(317006).

Open Access This article is distributed under the terms of the Creative Commons Attribution 4.0 International License (http:// creativecommons.org/licenses/by/4.0/), which permits unrestricted use, distribution, and reproduction in any medium, provided you give appropriate credit to the original author(s) and the source, provide a link to the Creative Commons license, and indicate if changes were made.

\section{References}

Chavan RR, Blouin AG, Cohen D, Pearson MN (2013) Characterization of the complete genome of a novel citrivirus infecting Actinidia chinensis. Arch Virol 158(8):1679-1686

Lim S, Igori D, Baek D, Cho IS, Choi GS, Moon JS (2017) First report of cherry virus A infecting Prunus mume in South Korea. VirusDisease 28(2):220-221

Wang J, Zhu D, Tan Y, Zong X, Wei H, Liu Q (2016) First report of Citrus leaf blotch virus in sweet cherry. Plant Dis 100(5):1027-1027

Publisher's note Springer Nature remains neutral with regard to jurisdictional claims in published maps and institutional affiliations. 